\title{
Minimally invasive endodontics: challenging prevailing paradigms
}

\author{
A. H. Gluskin, ${ }^{* 1}$ C. I. Peters ${ }^{1}$ and 0. A. Peters ${ }^{1}$
}

VERIFIABLE CPD PAPER
IN BRIEF
- Explains the structural weakening that occurs as a result of endodontic and restorative procedures.
- Recognises fracture susceptibility in all endodontically treated teeth and the predisposition for damage in functioning roots.
- Reflects upon the principles of cervical dentin preservation in stabilising load transfer to roots after endodontic procedures.

The primary goal of endodontic therapy is the long-term retention of a functional tooth by preventing or treating apical periodontitis. However, there are many other factors that impact endodontic outcomes such as the quality of the restoration and structural integrity of the tooth after root canal preparation. Contemporary research efforts are currently directed to better understanding dentin behaviour and structure during aging and function. An alternative approach is to minimise structural changes during root canal therapy, which may result in a new strategy that can be labelled 'minimally invasive endodontics.' This review addresses current clinical and laboratory data to provide an overview of this new endodontic paradigm.

\section{INTRODUCTION}

Technological advances in optics, instrumentation, materials, robotics, and computer systems over the last decades have introduced new strategies and possibilities to the medical profession. These innovations are clearly beneficial to patients by dramatically improving morbidity and mortality outcomes associated with many surgical procedures. ${ }^{1}$

Compared to medicine, such a shift to a non-invasive approach to surgery in dentistry $^{2}$ has been more moderate and cautious, perhaps with the exception of endodontic and periodontal microsurgery. ${ }^{3}$ It is difficult to directly compare operative procedures done to the human body versus those done on a tooth, however, a rational approach to dental procedures aiming to remove or reverse disease should be to conserve maximum structural integrity. This in turn has the potential to increase the functional prognosis for any given tooth.

The concept of minimally invasive endodontics calls for the treatment and prevention of pulpal pathoses and apical periodontitis, while causing the least amount of change to the dental hard tissues. This preserves the strength and function of the

'Department of Endodontics, University of the Pacific Arthur A. Dugoni School of Dentistry, 2155 Webster Street, San Francisco, CA 94115, United States

${ }^{*}$ Correspondence: Dr Alan H. Gluskin

Email:agluskin@pacific.edu

\section{Refereed Paper}

Accepted 11 December 2013

DOI: 10.1038/sj.bdj.2014.201

${ }^{\circledR}$ British Dental Journal 2014; 216: 347-353 endodontically treated tooth with the intent that it will last the patient's lifetime.

Just as in medicine, the dental surgeon treating endodontic disease must develop new skills and dexterity in order to adapt to a limited working environment within the confines of the pulpal space. These skills include working with new instruments and irrigants for cleaning the system; utilising advanced imaging modalities and computer software for demonstrating both the complexities of the root canal system and improving the accuracy of techniques; employing increased magnification and lighting for visualising the pulpal space as well as applying new materials that enhance the prognosis for restoring structure and retaining the natural dentition.

There are, however, currently no developed protocols for minimally invasive endodontics. The aim of this review is to illustrate the current status of non-surgical endodontic procedures highlighting the conservation of tooth structure to enhance longevity after root canal treatment.

\section{PRESERVING STRUCTURAL INTEGRITY}

It is apparent that remaining structural integrity of the tooth (Fig. 1) is a key factor that determines prognosis as it relates to future function of the tooth after restoration. ${ }^{4,5}$ Maintaining strength and stiffness that resists structural deformation becomes the recognised goal of all restorative procedures, especially in endodontics. Appreciation for the biomechanical behaviour of dentin, as the limiting strength

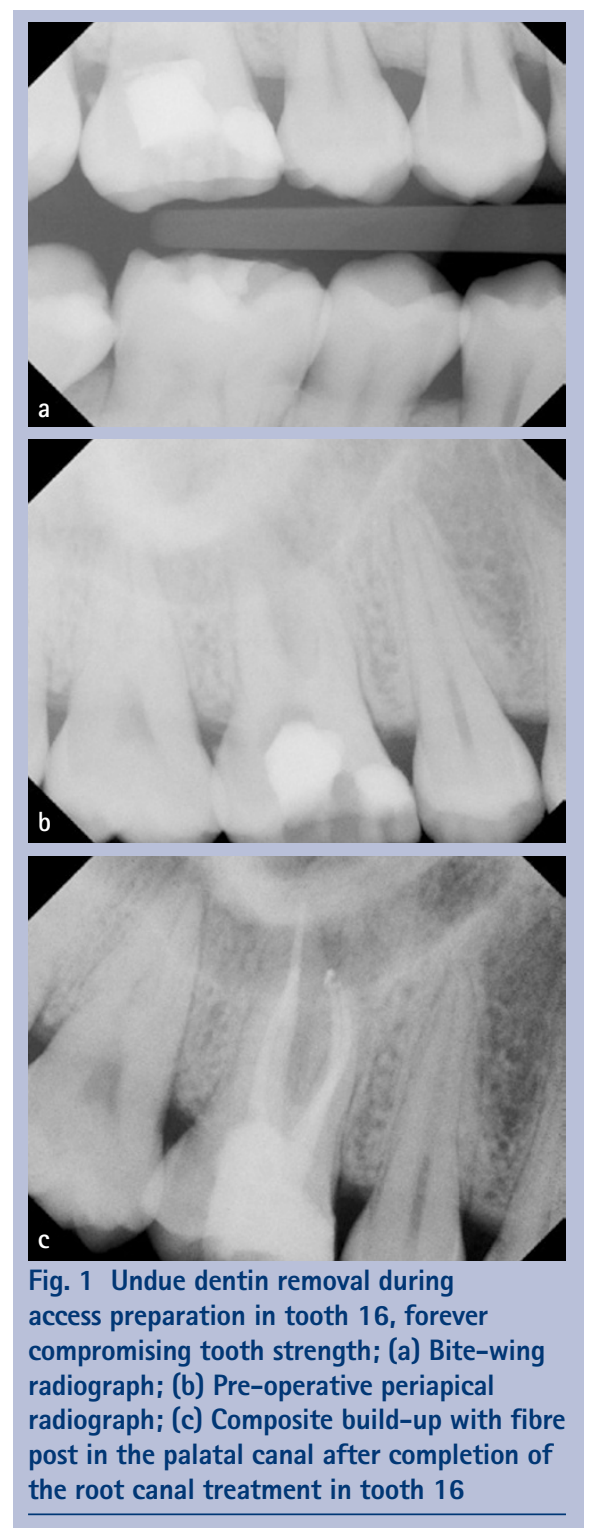


factor of any restorative complex, requires the recognition that dentin is weakened unequally by our restorative procedures. ${ }^{6}$

More than two decades ago a study was designed to compare the impact of endodontic versus restorative procedures on tooth strength. The stiffness of cusps was assessed when comparing traditional cavity preparations to endodontic access openings on bicuspid teeth. It was found that endodontic access openings by themselves have only a small (5\%) impact on tooth stiffness as opposed to any restorative preparation that removes the tooth's marginal ridges (for example, a MOD preparation) reducing cuspal stiffness by $63 \%$. The study identified approximately a 20\% loss of tooth strength with each prepared surface. These findings highlight that marginal ridges are a key factor in retaining tooth strength. ${ }^{7}$

Another fundamental understanding of dentin behaviour within remaining structure comes with the abandonment of the widely held clinical perception that endodontically treated teeth are more brittle and hence more vulnerable to fracture. An early investigation that demonstrated moisture loss of $9 \%$ after root treatment in dog's teeth gave credence to this hypothesis. ${ }^{8}$ While animal models have some translation to humans, there is currently an abundance of studies in human teeth showing that the dentin properties of endodontically treated teeth do not differ in any meaningful way from vital dentin. ${ }^{9-11}$ Conversely, the predominant reason that endodontically treated teeth are more prone to fracture relates more than any other attribute to the structural loss of those root treated teeth requiring restoration. Collectively, these studies show minimal dehydration effects from pulpal removal and demonstrate biomechanical behaviours in strength and toughness testing that are similar to vital dentin. ${ }^{9-11}$

Unfortunately, structural loss alone cannot answer every clinical question that relates to dentin failure. The relevance of fatigue as a main mechanism for tooth fracture and the resistance of dental tissues to both the initiation and propagation of cracks is an important research area. ${ }^{12,13}$ Recently, investigations have focused on the impact of chemical factors such as irrigants and medicaments on dentin; the effects of bacteria on the matrix of dentin; structural loss; the effect of post and core restorations and the results of age changes in dentin..$^{6,14}$ Of note, there is a reduction of up to $50 \%$ in the tensile strength and fatigue strength of coronal dentin in seniors (over 55 years) when compared to that of young adults. Similarly, the resistance to propagation of fatigue cracks in dentin decreases with
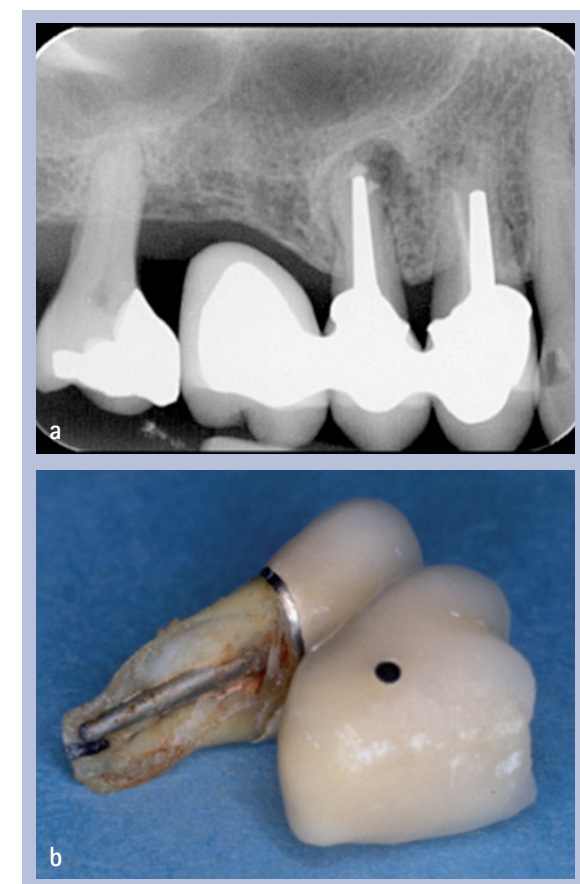

Fig. 2 Vertical root fracture originating from post preparation in tooth 15; (a) Periapical radiograph after attempted apical surgery; (b) Extracted tooth 15 after complete fracture. Note large and long post

increasing patient age and the incremental rate of crack extension is up to 100 times greater in seniors. ${ }^{15,16}$

\section{BIOMECHANICAL BEHAVIOUR OF DENTIN}

When endodontically treated teeth fail under function, that outcome is determined primarily by two aetiologies. Those causes stated most simply are: 1) the degree of stress experienced by the tooth under load, and 2) the inherent biomechanical properties of the remaining structure responsible for resisting fracture. It appears that, among technical elements of root canal therapy, access preparation and post preparation are most relevant in rendering the tooth more susceptible to significant destabilisation. ${ }^{17}$ Unfortunately, only a minimal number of long-term controlled clinical studies are available to assess the relationship between restoration, especially with posts, tooth fracture (Fig. 2) and the biomechanical behaviour of restored dentin. Within the limitations of bench top research, experimental evidence compels us to utilise 'best practices', yet our long-term data remains incomplete. The mechanical demands of human mastication create an endless number of impacting variables and only those long-term clinical outcomes remain the gold standard for evidence.

Teeth that physically fail through a vertical or unrestorable root fracture do not have to undergo endodontic treatment
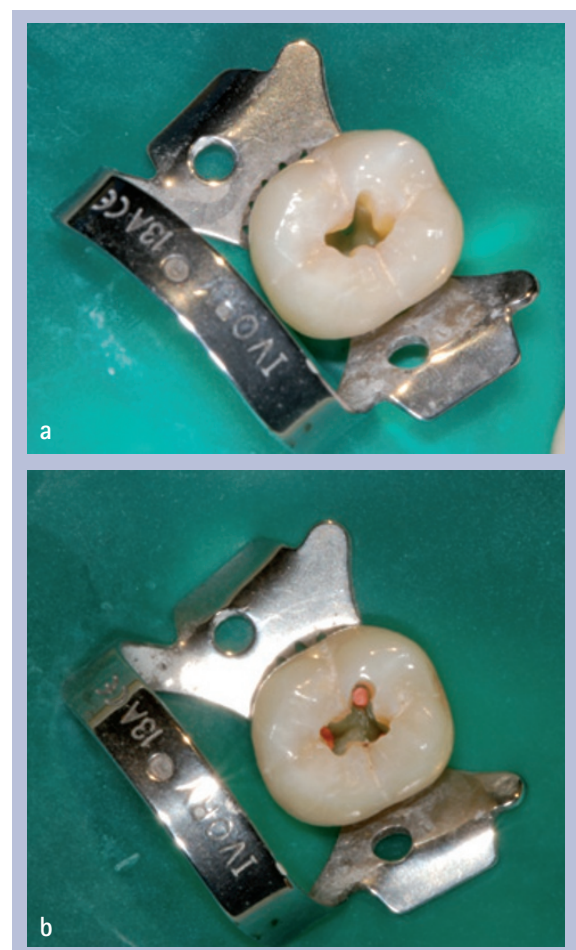

Fig. 3 Minimally invasive access preparation in tooth 37. (a) View of the access preparation; (b) After root canal filling

to experience this outcome. It has been demonstrated in the dental literature that all teeth, especially molars, can fracture without any endodontic treatment, and while some state this is not a common finding there are others who declare that the incidence is under-reported. ${ }^{18}$ However, when fracture occurs, it will inevitably have a devastating effect on both the periodontal attachment and the bone adjacent to the fracture. Once a fracture begins in the root and continues it is characterised by involvement of the root canal in the fracture progression; bacterial contamination of the failed section; fooddebris, cements, necrotic tissue and bacteria; as well as inflammation associated with a reactive periodontium. ${ }^{19}$ Studies involving Chinese populations have reported that fractures may occur within teeth with vital pulps in individuals with excessive or repetitive oral chewing habits. ${ }^{18}$ This is in agreement with Yeh who also suggested heavy masticatory forces as a cause for root fracture. ${ }^{20}$ In addition, root fractures seem to be more prevalent in seniors and male populations; pre-existing attrition is often a component of the condition. ${ }^{18,21}$

\section{MINIMALLY INVASIVE ACCESS STRATEGIES}

Root canal anatomy and the complexity of human pulpal systems provide significant challenges for endodontic therapy. The first priority of effective therapy is to access, shape and clean the system in a manner that will 
allow efficient and total filling of the root canal space, while leaving the tooth with sufficient strength to function successfully.

For almost a century endodontic textbooks have taught the student of dentistry to expose the pulp chambers of teeth with 'straightline' access to the orifice(s) of the root canal. Access cavities were to be prepared and expanded so that their smallest dimensions were dictated by the separation of the orifices on the pulpal floor and their widest dimensions were at the occlusal. In this era of enhanced lighting and magnification, as well as highly flexible rotary instruments, this approach to a doctrinaire access paradigm is being questioned as perhaps overly invasive of the tooth and an approach that may condemn a tooth to structural failure. ${ }^{22,23}$

Recently, maintaining structural integrity of the peri-cervical area of the tooth (about four mm above and below the alveolar crest) has been emphasised. Maintenance of the peri-cervical dentin (PCD), especially in molars is felt to be critical to their longterm survivability and optimum function. ${ }^{23}$ Some argue that in treatment planning for endodontics, on a molar tooth especially, clinicians must consider the significantly higher overall compressive forces that create a situation requiring a different set of rules for the calculation of ferrule, post and core design, resistance to fracturing, and most importantly, endodontic access (Fig. 3) and removal of radicular dentin during endodontic shaping. ${ }^{23}$

In keeping with this philosophy of minimal invasion of bulk dentin structure, the use of round burs and Gates-Glidden burs is now discouraged. While both of these types of instruments have been essential in endodontics for decades, they are now recognised in endodontic treatment as instruments that commonly gouge the endodontic access and the coronal third of the root canal (Fig. 4), those areas adjacent to the cemento-enamel junction (CEJ) of the tooth with critical structural prerequisites. Gouging of the access and coronal canal space must be avoided in order to preserve maximal resistance to structural flexure and ultimate failure. ${ }^{7,23}$ By directing the conservation of dentin and protecting dentin above and below the PCD the practitioner ensures a more viable and proven method to reinforce the endodontically treated tooth. No man-made material or technique can compensate for tooth structure lost in those key areas.

\section{SHAPING THE ROOT CANAL SPACE}

Root canals are sometimes depicted as smooth hollow tubes that are more or less tapered in shape. These misleading images

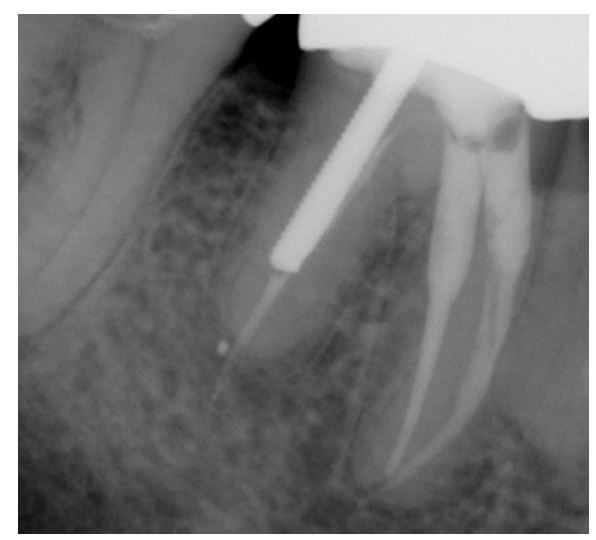

Fig. 4 Gouging of middle canal third due to use of Gates-Glidden bur in tooth 46

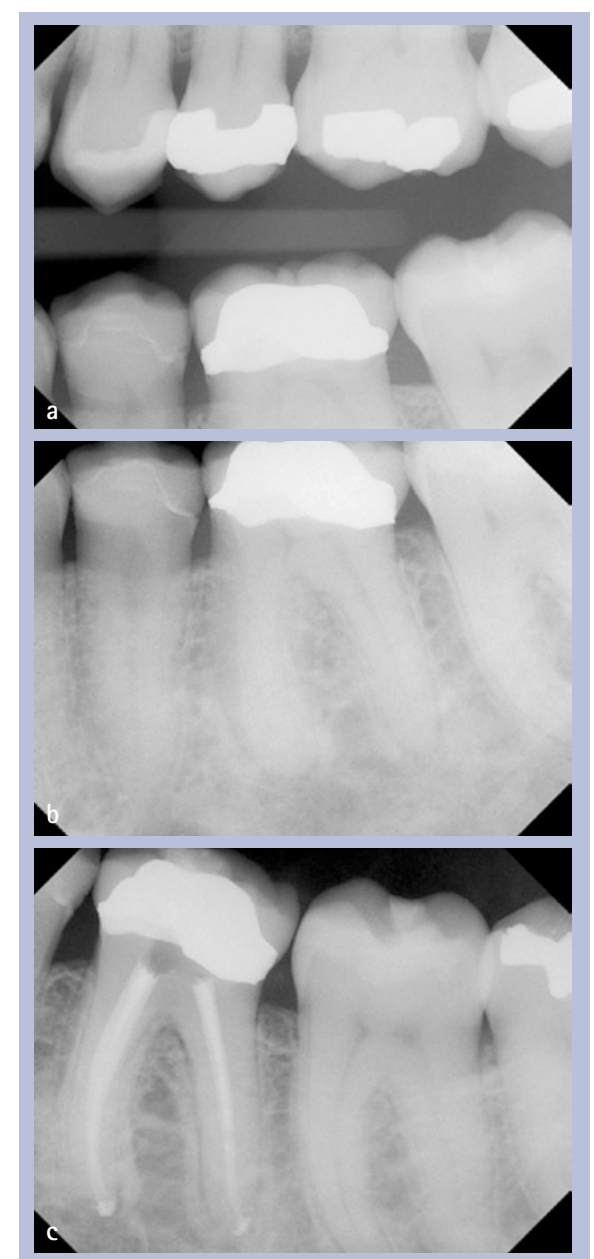

Fig. 5 Tapered preparation aligned with access preparation in tooth 36 ;

(a) Bite-wing radiograph; (b) Pre-operative periapical radiograph; (c) Completed root canal treatment and temporary filling

do not reflect the intricate anatomical structure and complexity of root canal systems. They are often asymmetrical or oval in cross section, they branch, dilacerate and divide and the canal walls show concavities and convexities. ${ }^{24}$ Complex root canal anatomy should be considered one of the most significant challenges in creating root canal shapes that will support good obturation outcomes and

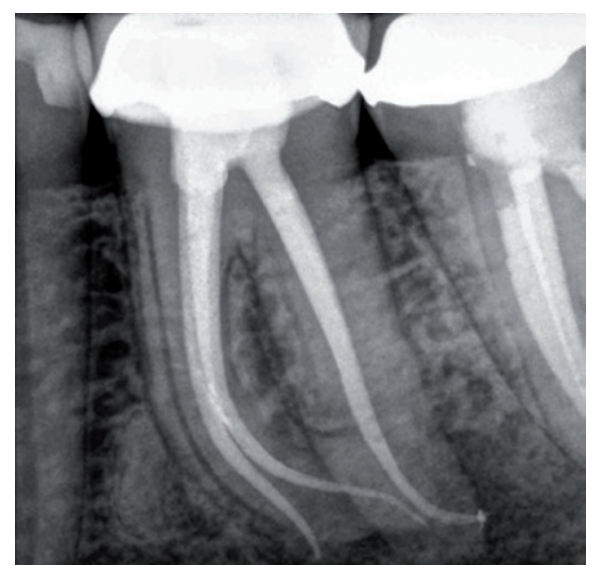

Fig. 6 Tooth 36: extremely long roots makes minimal preparation size a good strategy. Case by $\mathrm{Dr}$ Jordan West

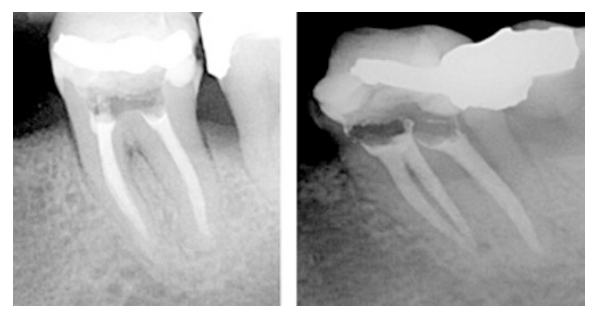

Fig. 7 Tooth 36: peparation of short canals to an apical size $55(\mathrm{mb}, \mathrm{ml}$ size 55 , d size 70$)$ in an attempt to be antimicrobially effective

leave sufficient remaining strength in the root. After biomechanical instrumentation, the completed root canal shapes need to withstand the internal compressive forces of obturation; provide sufficient resistance form to contain softened and compressible filling materials and retain enough strength for mastication (Fig. 5).

In a series of morphometric measurements on anterior and posterior teeth, Kerekes and Tronstad ${ }^{25-27}$ found a wide range of measurements at the apical constriction of all teeth, thus creating two separate philosophies for practitioners, each focused on its own set of evidence-based protocols supporting a position on how to clean these apical diameters and ultimately shape the root.

In another study that questioned our understanding of the true horizontal diameters necessary to clean the terminus, Jou et $a l .{ }^{28}$ coined the term 'working width' to alert clinicians to the critical need to understand the horizontal dimension of apical size and its clinical implication in cleaning the apical terminus.

Consequently, current shaping strategies employed by today's clinicians align with two general trends in contemporary endodontic practice. A significant number of practitioners believe that enhanced apical instrumentation and larger apical diameters with minimal taper in the canal shape leads to weakening of the root structure and a loss 


\begin{tabular}{|c|c|c|c|}
\hline Size & Ref. & Conclusion & Design \\
\hline Small & 54 & $\begin{array}{l}\text { There was no significant difference in intracanal bacterial reduction } \\
\text { when Ni-Ti GT rotary preparation with } \mathrm{NaOCl} \text { and EDTA irrigation was } \\
\text { used with or without apical enlargement preparation technique. It may } \\
\text { therefore not be necessary to remove dentin in the apical part of the } \\
\text { root canal when a suitable coronal taper is achieved to allow satisfactory } \\
\text { irrigation of the root canal system with antimicrobial agents. }\end{array}$ & in vitro \\
\hline$>\# 25$ & 55 & $\begin{array}{l}\text { Root canal enlargement to sizes larger than \# } 25 \text { appeared to improve } \\
\text { the performance of syringe irrigation. }\end{array}$ & in vitro \\
\hline \#30 & 56 & $\begin{array}{l}\text { The minimum instrumentation size needed for penetration of irrigants } \\
\text { to the apical third of the root canal is a \#30 file. }\end{array}$ & in vitro \\
\hline$>\# 30$ & 57 & $\begin{array}{l}\text { Root canal preparation to apical size } \# 30 \text { and tapers } 0.04,0.06 \text {, or } \\
0.08 \text { did not affect canal cleanliness. }\end{array}$ & in vitro \\
\hline \#40 & 58 & $\begin{array}{l}\text { The degree of root canal curvature decreased the volume of irrigant } \\
\text { at the working length for a given apical size and taper. An apical } \\
\text { preparation of \#40.06 significantly increased the volume and } \\
\text { exchange of irrigant at the working length regardless of curvature. }\end{array}$ & in vitro \\
\hline$\# 40$ & 59 & $\begin{array}{l}\text { An increase in apical preparation size and taper resulted in a } \\
\text { statistically significant increase in the volume of irrigant. In addition, } \\
\text { an apical enlargement to ISO \#40 with a } 0.04 \text { taper will allow for } \\
\text { tooth structure preservation and maximum volume of irrigation at the } \\
\text { apical third when using the apical negative pressure irrigation system. }\end{array}$ & in vitro \\
\hline$\# 40$ & 60 & $\begin{array}{l}\text { Endotoxin levels of dental root canals could be predicted by increasing } \\
\text { the apical enlargement size. Note: The diameters compared were } \\
\text { two sizes \#25/.06, 30/.05, 35/.04, 40/.04. }\end{array}$ & in vitro \\
\hline 'Large' & 61 & $\begin{array}{l}\text { Better microbial removal and more effective irrigation occurred when } \\
\text { canals were instrumented to larger apical sizes. Although bacteria } \\
\text { may remain viable in dentinal tubules proper instrumentation and } \\
\text { adequate irrigation significantly reduces bacteria from the canal and } \\
\text { the dentinal tubules. }\end{array}$ & review \\
\hline Large & 62 & $\begin{array}{l}\text { It was concluded that greater apical enlargement using LS rotary } \\
\text { instruments is beneficial as an attempt to further debride the apical } \\
\text { third region in mesiobuccal canals of mandibular molars. }\end{array}$ & in vitro \\
\hline $\begin{array}{l}\text { Inconclusive } \\
\text { or statistically } \\
\text { insignificant }\end{array}$ & 63 & $\begin{array}{l}\text { When comparing ProTaper size \#30; taper } 0.09-0.055 \text { and Hero Shaper } \\
\text { size \#30, taper } 0.04 \text {, both to the full WL, the difference between } \\
\text { changes in bacterial numbers achieved with two instrumentation } \\
\text { techniques was statistically not significant. }\end{array}$ & in vitro \\
\hline $\begin{array}{l}\text { Inconclusive } \\
\text { or statistically } \\
\text { insignificant }\end{array}$ & 64 & $\begin{array}{l}\text { Root canals with mild curvature prepared with the } \# 45.02 \text { instrument } \\
\text { to the full WL showed the highest values for extruded material to the } \\
\text { periapical region }(0.87 \pm 0.22) \text {. It seems more reasonable to establish } \\
\text { final instrument diameters based on the anatomic diameter after } \\
\text { cervical preparation. }\end{array}$ & in vitro \\
\hline $\begin{array}{l}\text { Inconclusive } \\
\text { or statistically } \\
\text { insignificant }\end{array}$ & 65 & $\begin{array}{l}\text { An appropriate apical sizing method can help the operator avoid } \\
\text { unnecessary enlargement of the apex whereas predictably reducing } \\
\text { intracanal debris. Method: During crown-down preparation, the first } \\
\text { crown-down file to reach the apex during instrumentation was noted } \\
\text { (CDF). Teeth were then divided into three master apical file size groups } \\
\text { of CDF }+1 \text {, CDF }+2 \text {, and CDF }+3 \text {. }\end{array}$ & in vitro \\
\hline
\end{tabular}

of control over the obturation component of treatment. They advocate smaller apical preparations, continuous taper, and a preparation that promotes resistance form, a tight apical seal and a conservative approach to creating sufficient shape for adequate disinfection (Fig. 6). Smaller apical sizes preserve dentin. The arguments are strategic and technique-driven, albeit often supported by inferred outcomes. The impetus for smaller apical sizes has been directed at the disinfection and obturation phase of endodontic therapy. ${ }^{29-32}$

On the other hand, there is a significant body of literature that presents evidence that larger apical canal diameters (Fig. 7) are important to shape the apical canal wall, flush debris, allow deeper irrigation to the terminus and decrease remaining bacterial contamination in the system. ${ }^{33-38}$ Studies vary on which size diameter will accomplish maximum cleaning. Some researchers have suggested file diameters ranging from \#35-\#45 to accomplish significant bacterial reduction. Others have shown that minimal sizes can accomplish this task as adequately as larger diameters. ${ }^{40,41}$ What is remarkably clear from the evidence is that no matter which school of thought one ascribes to, it is not possible that any apical preparation technique will render the terminus entirely free of bacterial contamination in an infected canal. ${ }^{24,42}$ In essence, structural considerations in
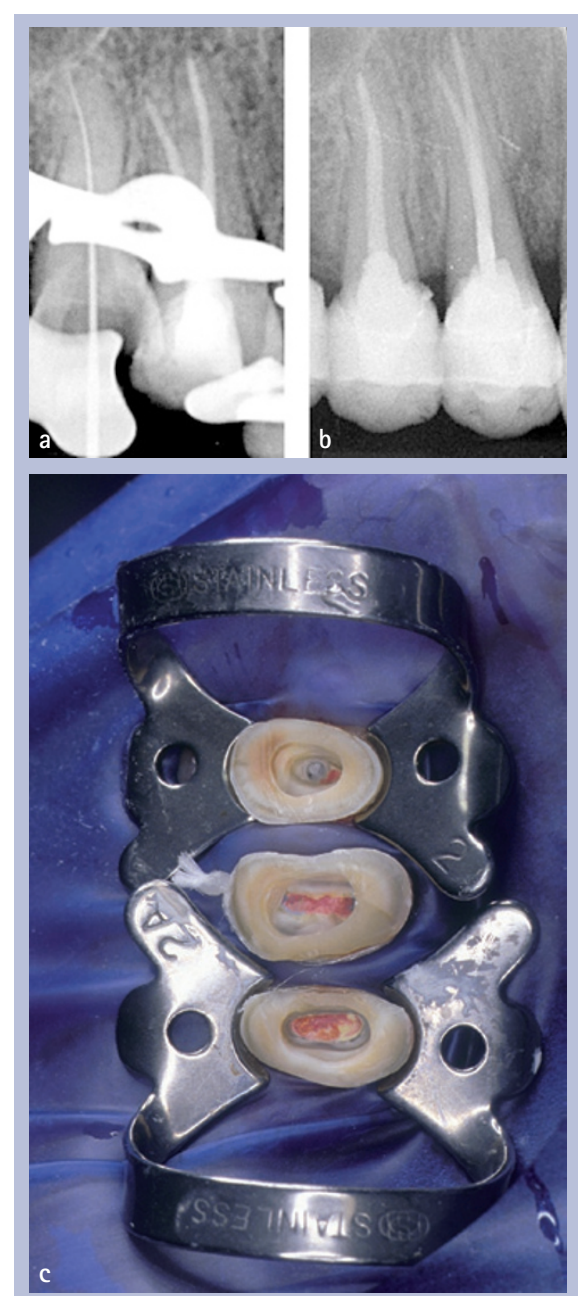

Fig. 8 Adhesive build-up with orifice plugs in teeth $13,14,15$ as part of a full-mouth rehabilitation. Restorative treatment by $\mathrm{Dr}$ Till N. Göhring; (a) Periapical radiograph teeth 14, 15; (b) Postoperative periapical radiograph with permanent restoration and composite build-ups into the coronal root canal area; (c) Corresponding clinical view of teeth prepared for adhesive build-up

shaping continue to remain a compelling argument for conservative shapes.

Weine et al. ${ }^{43}$ and others ${ }^{44,45}$ have described and elucidated the structural damage and preparation errors that can occur while shaping root canals with stainless steel instruments to large sizes. Transportation, ledging, apical perforation and loss of the original canal position are all well recognised shaping errors that often lead to loss of working length, ledging and damage to the apical terminus leading to weakening of the root structure at its most fragile levels.

There is now a large body of conclusive research quantifying the use of rotary and hand nickel-titanium instruments first described by Walia, ${ }^{46}$ who report that the use of this super-elastic metal alloy offers less straightening and better centered preparations compared to traditional stainless steel instruments in preparing the wide range of anatomical variability seen in teeth. ${ }^{47-52}$ 
These studies have focused on the geometry of shape produced by these instruments alone or in combination with stainless steel; including conicity, taper, flow and maintenance of original canal position. Most of these studies have recorded the degree of change from original position and have measured the loss of original canal positions based on the definitions by Weine. ${ }^{43}$ In comparing stainless steel versus nickel-titanium, researchers have focused on both the metallurgy of the systems and the systems themselves. ${ }^{52,53}$ Collectively these studies suggest that Nickel-titanium technology alone or in combination with the conservative use of stainless steel instruments provides shapes that are better centered, maintaining the original canal positions with greater conservation of dentin and safer radicular preparations.

\section{DISINFECTION AND OTHER CONSIDERATIONS IN MINIMALLY INVASIVE ENDODONTICS}

In order to address the microbiologic aetiology of endodontic disease, that is, periapical inflammation, disinfection is and will always remain, a key element of the overall treatment strategy. At first glance, any minimally invasive approach to root canal treatment is at conflict with disinfection. Microbiological studies in vitro, however, do not provide a definitive answer as to the required preparation size for antimicrobial efficacy. Table 1 shows selected studies suggesting a wide range of apical sizes. More recently a clinical study rekindled the notion of a preparation 'three sizes larger than the initial size';66 however, a large clinical data set does not support any particular canal shape as being associated with apical healing ${ }^{67}$ or retention of a root canal-treated tooth. ${ }^{68}$

Current cleaning and shaping methods appear to be unlikely to predictably remove all bio-burden from the root canal system. Therefore, and particularly under the conditions of smaller apical preparation sizes, the search continues for techniques to enhance irrigation efficacy. The possibilities for physical means that enable enhanced disinfection vary from ultrasonic or sonic activation up to and including laser activation. ${ }^{69-71}$

In the absence of adequate models for clinical outcomes, only direct clinical studies assessing both apical bone fill and tooth function/survival will provide convincing evidence regarding canal disinfection efficacy.

The effect of a modified access cavity design has only recently been tested in extracted teeth. Using a combined microcomputed tomography and load-to-failure approach, Krishan et $a .^{72}$ found that in premolars shaping was not impacted and load to failure was significantly higher for teeth with minimal access cavity designs.

While the idea of minimally invasive endodontics has been promoted recently, there is a scarcity of independent evaluations for such a strategy. For example, root canal preparation instruments sometimes associated with this strategy such as V-Taper (SS White, Lakewood, NJ, USA) and EndoEZE AET (Ultradent, South Jordan UT, USA) have not been shown to actually perform in a superior way to traditional rotary instrumentation in the laboratory. ${ }^{73,74}$

Another aspect of this discussion is the finding of micro-cracks induced by various rotary shaping procedures in canal preparation. In recent years several investigations have illustrated such microcracks in extracted teeth. ${ }^{75,76}$ While it is not clear at this point if such cracks are generated in vivo, it may be reasonable to develop instruments that reduce vibration and rotational stresses during intracanal procedures in an effort to lessen additional loads on a structurally weakened root.

Micro-computed tomography studies not only show overall canal shaping outcomes $^{47-52}$ but have also demonstrated that hard tissue debris is compacted into unshaped canal areas rendering them potentially inaccessible to irrigation. ${ }^{77}$ It is likely future root canal preparation techniques will have to focus on balancing disinfection capacity and iatrogenic damage with enhanced debridement and disinfection.

\section{RESTORATION STRATEGIES FOR MAXIMUM PROTECTION AND MINIMAL INVASION}

Patients are not well served if the endodontic treatment is successful but the tooth fails, especially with the emergence of implants into the mainstream of dentistry and their choice as an alternative to saving the natural dentition. ${ }^{78}$ In extensive reviews of evidence surrounding the restoration of endodontically treated teeth, preserving intact coronal and radicular tooth structure, especially maintaining the peri-cervical structure to allow a substantial 'ferrule effect', is considered to be crucial for the optimal biomechanical behaviour of restored teeth. ${ }^{79,80}$ Encircling the parallel walls of remaining dentin with the crown margin allows a ferrule that provides a protective effect by reducing stresses within a tooth. The presence of a 1.5 to $2 \mathrm{~mm}$ ferrule has a positive effect on fracture resistance of endodontically treated teeth. ${ }^{81-84}$ Teeth with a ferrule of one $\mathrm{mm}$ of vertical tooth structure doubled the resistance to fracture compared with teeth restored without a ferrule. ${ }^{82}$ Even if the clinical situation does not permit a circumferential ferrule, an incomplete ferrule is considered a better option than a complete lack of ferrule. ${ }^{85,86}$ However, it can be generally concluded that providing an adequate ferrule lessens the destabilising impact of the post and core system ${ }^{85,87,88}$ and the final restoration ${ }^{81}$ in the long-term performance of restored root treated teeth.

When it comes to severely damaged teeth with little or no coronal structure, in order to provide space for a ferrule, orthodontic extrusion should be considered rather than surgical crown lengthening. This approach preserves more tooth structure and ensures a more favourable biomechanical behaviour of remaining dentin structure..$^{89,90}$ If neither of the alternative methods for providing a ferrule for the restoration can be performed, currently available evidence suggests that a poor treatment outcome and the ultimate the loss of the tooth has a high probability. 5,82,91,92

\section{IS ROOT STRENGTHENING A POSSIBILITY?}

The past decade has seen a considerable change in clinical strategies for using and placing posts. An advancing principle promoting minimally invasive therapy directs the nominal use of posts in endodontically treated teeth. That principle, based on evidence, affirms that retaining tooth structure is more valuable than the use of a post in almost every circumstance where adequate structure exists for a ferrule. ${ }^{93,94}$ The long-term success of endodontic treatment has always been highly dependent on the restorative treatment that follows. A restored tooth must be structurally sound and the sealed state of the root canal system must be maintained. Most endodontically treated teeth today are restored with adhesive materials. Adhesive bonding provides an immediate seal of the pulpal spaces and some immediate toughening of the tooth. These materials are generally not dependent on gross mechanical retention, so tooth structure can be preserved and these materials can certainly be termed minimally invasive (Fig. 8).

Conventional thought has been that posts do not 'reinforce' the root. Early restorative protocols considered this true for metal posts, but there is now a growing body of evidence that bonded fibre posts can be placed with no removal of dentin structure, may protect the root and make it more resistant to fracture. Fibre-reinforced resin posts were introduced over 20 years ago with the intent to provide more elastic support to the core. The reduced stress transfer to tooth structure lowered the likelihood of 
root fracture. In addition, posts made of materials with a modulus of elasticity similar to dentin were considered more resilient; able to absorb similar impact forces, and distribute the forces of mastication in a more protective manner to remaining dentin than stiffer metallic posts. ${ }^{78,94}$ Based on the aforementioned evidence, it may be premature to describe adhesive technology as 'reinforcing' or 'root strengthening' but in terms of distributing forces throughout the remaining dentin structure it may certainly be deemed 'protective'.

\section{CONCLUSION}

The causes for post-treatment loss of teeth after endodontic therapy, when the therapy itself has been successful, have been described in this article by citing many diverse authorities. The loss of a tooth after successful endodontic therapy can invariably be attributed to one or more predictable explanations.

Often these sequelae are clinically avoidable and the result of an approach to therapy that is far more invasive than required to remove and cure the causes of apical periodontitis. These outcomes include: - Poor access cavity design and execution

- An iatrogenic or procedural mishap weakening peri-cervical integrity

- Instrumentation errors such a ledging, perforation, transportation from centre

- Coronal leakage and recontamination of the pulpal space

- Crown and root fracture.

As practitioners of the art and science of dentistry, poor outcomes in the course of endodontic treatment should encourage reflection on the careful and prudent practice of endodontics that safeguards against undesired consequences. Our obligation as experts is to protect patients from iatrogenic harm. This responsibility is met when we as a profession can provide advanced and sophisticated therapies in a safe and controlled manner with preservation of the dentition as an overriding priority in all aspects of our treatments.

1. Lamata P, Ali W, Cano A et al. Augmented reality for minimally invasive surgery: overview and some recent advances, In Soha Maad (ed) Augmented reality. Croatia: INTECH, 2010.

2. Murdoch-Kinch $C A$, McLean M E. Minimally invasive dentistry. J Am Dent Assoc 2003; 134: 87-95.

3. Kim S. Principles of endodontic microsurgery. Dent Clin North Am 1997; 41: 481-497.

4. Tang $W, W u$ Y, Smales R J. Identifying and reducing risks for potential fractures in endodontically treated teeth. J Endod 2010; 36: 609-617.

5. Nagasiri $R$, Chitmongkolsuk $S$. Long-term survival of endodontically treated molars without crown coverage: A retrospective cohort study. J Prosthet Dent 2005; 93: 164-170.

6. Kishen A. Mechanisms and risk factors for fracture predilection in endodontically treated teeth. Endod
Topics 2006; 13: 57-83

7. Reeh E S, Messer H H, Douglas W H. Reduction in tooth stiffness as a result of endodontic and restorative procedures. J Endod 1989; 15: 512-516.

8. Helfer A R, Melnick S, Schilder H. Determination of the moisture content of vital and pulp less teeth. Oral Surg Oral Med Oral Pathol 1972; 34: 661-670.

9. Sedgley $\mathrm{C} M$, Messer $\mathrm{H} H$. Are endodontically treated teeth more brittle? J Endod 1992; 18: 332-335.

10. Papa J, Cain C, Messer H H. Moisture content of vital vs endodontically treated teeth. Endod Dent Traumatol 1994; 10: 91-93.

11. Huang T J, Schilder $H$, Nathanson D. Effects of moisture content and endodontic treatment on some mechanical properties of human dentin. J Endod 1992; 18: 209-215.

12. Arola D, Ivancik J, Majd H et al. Microstructure and mechanical behaviour of radicular and coronal dentin. Endod Topics 2012; 20: 30-51.

13. Arola D, Reprogel R K. Effects of aging on the mechanical behaviour of human dentin. Biomaterials 2005; 26: 4051-4061.

14. Gutmann J L. The dentin-root complex: anatomic and biologic considerations in restoring endodontically treated teeth. J Prosthet Dent 1992: 67: 458-467.

15. Nazari A, Bajaj D, Zhang D, Romberg E, Arola D. On the reduction in fracture toughness of human dentin with age. J Mech Behav Biomed Mater 2009; 2: $550-559$.

16. Koester K J, Ager J W 3rd, Ritchie R 0. The effect of aging on crack-growth resistance and toughening mechanisms in human dentin. Biomaterials 2008; 29: $1318-1328$

17. Lang H, Korkmaz Y, Schneider K, Raab W H. Impact of endodontic treatments on the rigidity of the root. J Dent Res 2006; 85: 364-368.

18. Chan C P, Tseng S C, Lin C P, Huang C C, Tsai T P, Chen C C. Vertical root fracture in nonendodontically treated teeth - a clinical report of 64 cases in Chinese patients J Endod 1998; 24: 678-681.

19. Walton $R$, Michelich $R$, Smith $G$. The histopathogenesis of vertical root fractures. J Endod 1984; 10: 48-56.

20. Yeh C J. Fatigue root fracture: a spontaneous root fracture in nonendodontically treated teeth. Br Dent J 1997: 182: 261-266.

21. Yang S F, Rivera E M, Walton R E. Vertical root fracture in non-endodontically treated teeth. J Endod 1995; 21: 337-339.

22. Peters $0 \mathrm{~A}$. Accessing root canal systems: knowledge base and clinical techniques. ENDO 2008; 2: 87-104.

23. Clark D, Khademi J A. Case studies in modern molar endodontic access and directed dentin conservation. Dent Clin North Am 2010; 54: 249-273.

24. Wu M K, Dummer P M, Wesselink P R. Consequences of and strategies to deal with residual posttreatment root canal infection. Int Endod J 2006: 39: 343-356.

25. Kerekes K, Tronstad L. Morphometric observations on human anterior teeth. J Endod 1977; 3: 24-29.

26. Kerekes K, Tronstad L. Morphometric observations on human premolars. J Endod 1977; 3: 74-79.

27. Kerekes K, Tronstad L. Morphometric observations on human molars. J Endod 1977; 3: 114-118.

28. Jou Y T, Karabucak B, Levin J, Liu D. Endodontic working width: current concepts and techniques. Dent Clin North Am 2004; 48: 323-335.

29. Buchanan LS. Management of the curved root canal. J Calif Dent Assoc 1989; 17: 40-47.

30. Buchanan LS. The standardized-taper root canal preparation: part 1. Concepts for variably tapered shaping instruments. Int Endod J 2000; 33: 516-529.

31. Buchanan LS. The standardized-taper root canal preparation: part 2. GT file selection and safe handpiece-driven file use. Int Endod J 2001; 34: 63-71.

32. Ruddle C J. Cleaning and shaping the root canal system. In Cohen S, Burns R C (eds) Pathways of the pulp. 8th ed. pp 231-291. St. Louis: Mosby, 2002.

33. Weiger $R$, Bartha $T$, Kalwitzki M, Löst C. A clinical method to determine the optimal apical preparation size. Part I. Oral Surg Oral Med Oral Pathol Oral
Radiol Endod 2006; 102: 686-691.

34. Salzgeber R M, Brilliant J D. An in vivo evaluation of the penetration of an irrigating solution in root canals. J Endod 1977; 3: 394-398.

35. Chow T. Mechanical effectiveness of root canal irrigation. J Endod 1983; 9: 475-479.

36. Shuping G, Orstavik D, Sigurdsson A, Trope M. Reduction of intracanal bacteria using nickeltitanium rotary instrumentation and various medications. J Endod 2000; 26: 751-755.

37. Siqueira J, Lima $K_{\text {, Magalhaes }} \mathrm{A}_{\text {, Lopes }} \mathrm{H}_{\text {, }}$ de Uzeda M. Mechanical reduction of the bacterial population in the root canal by three instrumentation techniques. J Endod 1999; 25: 332-335.

38. Dalton B C, Orstavik D, Phillips C, Pettiette M, Trope M. Bacterial reduction with nickel-titanium rotary instrumentation. J Endod 1998; 24: 763-767.

39. Sjogren U S, Figdor D, Spangberg L, Sundqvist G. The antimicrobial effect of calcium hydroxide as a short-term intracanal dressing. Int Endod J 1991; 24: 119-125.

40. Yared G M, Dagher F E. Influence of apical enlargement on bacterial infection during treatment of a pical periodontitis. J Endod 1994; 20: 535-537.

41. Ørstavik D, Qvist V, Stoltze K. A multivariate analysis of the outcome of endodontic treatment. Eur J Oral Sci 2004: 112: 224-230.

42. Siqueira J F, Araújo M C, Garcia P F, Fraga R C, Sabóia Dantas C J. Histological evaluation of the effectiveness of five instrumentation techniques for cleaning the apical third of root canals. J Endod 1997; 23: 499-502.

43. Weine F S, Kelly R E, Lio P J. The effect of preparation procedures on original canal shape and on apical foramen shape. J Endod 1975; 1: 255-262.

44. Roane J B, Sabala C L, Duncanson M G. The "balanced force" concept for instrumentation of curved canals. J Endod 1985; 11: 203-211.

45. Kyomen S M, Caputo A A, White S N. Critical analysis of the balanced force technique in endodontics. J Endod 1994; 20: 332-337.

46. Walia $H$, Brantley W A, Gerstein H. An initial investigation of the bending and torsional properties of Nitinol root canal files. J Endod 1988; 14: 346-351.

47. Peters $O A$, Laib A, Rüegsegger P, Barbakow F. Threedimensional analysis of root canal geometry using high resolution computed tomography. J Dent Res 2000; 79: 1405-1409.

48. Peters 0 A, Schönenberger $K$, Laib A. Effects of four NiTi preparation techniques on root canal geometry assessed by micro computed tomography. Int Endod J. 2001; 34: 221-230.

49. Peters 0 A, Laib A, Göhring T N, Barbakow F. Changes in root canal geometry after preparation assessed by high-resolution computed tomography. J Endod 2001; 27: 1-6.

50. Peters $O A$, Peters $C I$, Schönenberger $K$, Barbakow $F$. ProTaper rotary root canal preparation: effects of canal anatomy on final shape analysed by micro CT. Int Endod J 2003: 36: 86-92.

51. Hübscher W, Barbakow F, Peters O A. Root canal preparation with FlexMaster: canal shapes analysed by micro-computed tomography. Int Endod J 2003; 36: 740-747.

52. Gluskin A H, Brown D C, Buchanan L S. A reconstructed computerized tomographic comparison of Ni-Ti rotary GT files versus traditional instruments in canals shaped by novice operators. Int Endod J 2001; 34: 476-484.

53. Luiten D J, Morgan L A, Baumgartner J C, Marshall J G. A comparison of four instrumentation techniques on apical transportation. J Endod 1995; 21: 26-32.

54. Coldero L G, McHugh S, MacKenzie D, Saunders W P. Reduction in intracanal bacteria during root canal preparation with and without apical enlargement. Int Endod J 2002; 35: 437-446.

55. Boutsioukis C, Gogos C, Verhaagen B, Versluis M, Kastrinakis E, Van der Sluis L W. The effect of root canal taper on the irrigant flow: evaluation using an unsteady computational fluid dynamics model. Int Endod J 2010; 43: 909-916.

56. Khademi A, Yazdizadeh M, Feizianfard M 
Determination of the minimum instrumentation size for penetration of irrigants to the apical third of root canal systems. J Endod 2006; 32: 417-420.

57. Arvaniti IS, Khabbaz M G. Influence of root canal taper on its cleanliness: a scanning electron microscopic study. J Endod 2011; 37: 871-874.

58. de Gregorio C, Arias A, Navarrete N, Del Rio V, Oltra $\mathrm{E}$, Cohenca N. Effect of apical size and taper on volume of irrigant delivered at working length with apical negative pressure at different root curvatures. J Endod 2013; 39: 119-124.

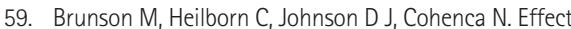
of apical preparation size and preparation taper on irrigant volume delivered by using negative pressure irrigation system. J Endod 2010; 36: 721-724.

60. Marinho A C, Martinho F C, Zaia A A, Ferraz C C, Gomes B P. Influence of the apical enlargement size on the endotoxin level reduction of dental root canals. J Appl Oral Sci 2012; 20: 661-666.

61. Baugh D, Wallace J. The role of apical instrumentation in root canal treatment: a review of the literature. J Endod 2005; 31: 330-340.

62. Tan B T, Messer H H. The quality of apical canal preparation using hand and rotary instruments with specific criteria for enlargement based on initial apical file size. J Endod 2002; 28: 658-664.

63. Aydin C, Tunca Y M, Senses Z, Baysallar M, Kayaoglu $\mathrm{G}$, Orstavik D. Bacterial reduction by extensive versus conservative root canal instrumentation in vitro. Acta Odontol Scand 2007; 65: 167-170.

64. Borges M F, Miranda C E, Silva S R, Marchesan $M$. Influence of apical enlargement in cleaning and extrusion in canals with mild and moderate curvatures. Braz Dent J 2011; 22: 212-217.

65. Mickel A K, Chogle S, Liddle J, Huffaker K, Jones $J J$. The role of apical size determination and enlargement in the reduction of intracanal bacteria. J Endod 2007; 33: 21-23.

66. Saini H R, Tewari S, Sangwan P, Duhan J, Gupta A. Effect of different apical preparation sizes on outcome of primary endodontic treatment: a randomized controlled trial. J Endod 2012; 38: 1309-1315.

67. Ng Y L, Mann V, Gulabivala K. A prospective study of the factors affecting outcomes of nonsurgical root canal treatment: part 1: periapical health. Int Endod J 2011: 44: 583-609.

68. Ng Y L, Mann V, Gulabivala K. A prospective study of the factors affecting outcomes of nonsurgical root canal treatment: part 2: tooth survival. Int Endod J 2011; 44: 610-625.

69. Huffaker S K, Safavi K, Spangberg LS, Kaufman B. Influence of a passive sonic irrigation system on the elimination of bacteria from root canal systems: a clinical study. J Endod 2010; 36: 1315-1318.
70. Klyn S L, Kirkpatrick T C, Rutledge R E. In vitro comparisons of debris removal of the EndoActivator system, the $\mathrm{F}$ file, ultrasonic irrigation, and $\mathrm{NaOCl}$ irrigation alone after hand-rotary instrumentation in human mandibular molars. J Endod 2010; 36: 1367-1371.

71. Peters $O A$, Bardsley S, Fong J, Pandher G, Divito E. Disinfection of root canals with photon-initiated photoacoustic streaming. J Endod 2011; 37: 1008-1012.

72. Krishan $R$, Paqué $F$, Dao $T$, Kishen $A$, Friedman $S$. Root canal instrumentation performed through conservative endodontic access: a micro-CT assessment in incisors, premolars and molars [OR 66]. J Endod 2013; 39: e18.

73. Paqué $F$, Barbakow F, Peters 0 A. Root canal preparation with Endo-Eze AET: changes in root canal shape assessed by micro-computed tomography. Int Endod J 2005: 38: 456-464.

74. Akhlaghi N M, Kahali R, Abtahi A, Tabatabaee S, Mehrvarzfar P, Parirokh M. Comparison of dentine removal using $\mathrm{V}$-taper and $\mathrm{K}$-Flexofile instruments. Int Endod J 2010; 43: 1029-1036.

75. Bier C A, Shemesh H, Tanomaru-Filho M, Wesselink $P R, W u M K$. The ability of different nickel-titanium rotary instruments to induce dentinal damage during canal preparation. J Endod 2009; 35: 236-238.

76. Bürklein S, Tsotsis P, Schäfer E. Incidence of dentinal defects after root canal preparation: reciprocating versus rotary instrumentation. J Endod 2013; 39: 501-514.

77. Paqué $F$, Boessler $C$, Zehnder M. Accumulated hard tissue debris levels in mesial roots of mandibular molars after sequential irrigation steps. Int Endod $J$ 2011: 44: 148-153.

78. Ree $M$, Schwartz R S. The endo-restorative interface: current concepts. Dent Clin North Am 2010; 54: 345-374.

79. Dietschi D, Duc O, Krejci I, Sadan A. Biomechanical considerations for the restoration of endodontically treated teeth: a systematic review of the literaturepart 1. Composition and micro-and macrostructure alterations. Quintessence Int 2007; 38: 733-743.

80. Dietschi D, Duc O, Krejci I, Sadan A. Biomechanical considerations for the restoration of endodontically treated teeth: a systematic review of the literature, part II (evaluation of fatigue behaviour, interfaces, and in vivo studies). Quintessence Int 2008; 39: 117-129.

81. Juloski J, Radovic I, Goracci C, Vulicevic Z R, Ferrari M. Ferrule effect: a literature review. J Endod 2012; 38: $11-19$.

82. Sorensen J A, Martinoff J T. Intracoronal reinforcement and coronal coverage: a study of endodontically treated teeth. J Prosthet Dent 1984; 51: 780-784

83. Ross I F. Fracture susceptibility of endodontically treated teeth. J Endod 1980; 6: 560-565.

84. Barkhordar R A, Radke R, Abbasi J. Effect of metal collars on resistance of endodontically treated teeth to root fracture. J Prosthet Dent 1989; 61: 676-678.

85. Tan P L, Aquilino S A, Gratton D G et al. In vitro fracture resistance of endodontically treated central incisors with varying ferrule heights and configurations. J Prosthet Dent 2005; 93: 331-336.

86. Dikbas I, Tanalp J, Ozel E, Koksal T, Ersoy M. Evaluation of the effect of different ferrule designs on the fracture resistance of endodontically treated maxillary central incisors incorporating fibre posts, composite cores and crown restorations. J Contemp Dent Pract 2007; 8: 62-69.

87. da Silva N R, Raposo L H, Versluis A, FernandesNeto A J, Soares C J. The effect of post, core, crown type, and ferrule presence on the biomechanical behaviour of endodontically treated bovine anterior teeth. J Prosthet Dent 2010; 104: 306-317.

88. Libman W J, Nicholls J I. Load fatigue of teeth restored with cast posts and cores and complete crowns. Int J Prosthodont 1995; 8: 155-161.

89. Meng $Q \mathrm{~F}$, Chen L J, Meng J, Chen Y M, Smales $\mathrm{R} J$, Yip K H. Fracture resistance after simulated crown lengthening and forced tooth eruption of endodontically-treated teeth restored with a fibre post-and-core system. Am J Dent 2009; 22: 147-150.

90. Meng Q F, Chen Y M, Guang H B, Yip K H, Smales $R \mathrm{~J}$. Effect of a ferrule and increased clinical crown length on the in vitro fracture resistance of premolars restored using two dowel and-core systems. Oper Dent 2007; 32: 595-601.

91. Salehrabi R, Rotstein I. Endodontic treatment outcomes in a large patient population in the USA: an epidemiological study. J Endod 2004; 30: 846-850.

92. Aquilino S A, Caplan D J. Relationship between crown placement and the survival of endodontically treated teeth. J Prosthet Dent 2002; 87: 256-263.

93. Goodacre C J, Spolnik K J. The prosthodontic management of endodontically treated teeth: a literature review. Part I. Success and failure data, treatment concepts. J Prosthodont 1994; 3 : 243-250.

94. Sterzenbach G, Franke A, Naumann M. Rigid versus flexible dentine-like endodontic posts - Clinical testing of a biomechanical concept: seven-yea results of a randomized controlled clinical pilot trial on endodontically treated abutment teeth with severe hard tissue loss. J Endod 2012; 38: 1557-1563. 